\title{
Acetyl Phosphate as a Primordial Energy Currency at the Origin of Life
}

\author{
Alexandra Whicher ${ }^{1} \cdot$ Eloi Camprubi $^{1} \cdot$ Silvana Pinna $^{1}$. \\ Barry Herschy $^{1} \cdot$ Nick Lane $^{1}$ (D)
}

Received: 13 April 2016/Accepted: 24 January 2018 /

Published online: 3 March 2018

(C) The Author(s) 2018. This article is an open access publication

\begin{abstract}
Metabolism is primed through the formation of thioesters via acetyl CoA and the phosphorylation of substrates by ATP. Prebiotic equivalents such as methyl thioacetate and acetyl phosphate have been proposed to catalyse analogous reactions at the origin of life, but their propensity to hydrolyse challenges this view. Here we show that acetyl phosphate (AcP) can be synthesised in water within minutes from thioacetate (but not methyl thioacetate) under ambient conditions. AcP is stable over hours, depending on temperature, $\mathrm{pH}$ and cation content, giving it an ideal poise between stability and reactivity. We show that AcP can phosphorylate nucleotide precursors such as ribose to ribose-5-phosphate and adenosine to adenosine monophosphate, at modest $(\sim 2 \%)$ yield in water, and at a range of $\mathrm{pH}$. AcP can also phosphorylate ADP to ATP in water over several hours at $50{ }^{\circ} \mathrm{C}$. But AcP did not promote polymerization of either glycine or AMP. The amino group of glycine was preferentially acetylated by AcP, especially at alkaline $\mathrm{pH}$, hindering the formation of polypeptides. AMP formed small stacks of up to 7 monomers, but these did not polymerise in the presence of AcP in aqueous solution. We conclude that AcP can phosphorylate biologically meaningful substrates in a manner analogous to ATP, promoting the origins of metabolism, but is unlikely to have driven polymerization of macromolecules such as polypeptides or RNA in free solution. This is consistent with the idea that a period of monomer (cofactor) catalysis preceded the emergence of polymeric enzymes or ribozymes at the origin of life.
\end{abstract}

Keywords Acetyl phosphate ATP. Thioester P Phosphorylation · Metabolism · Origin of life

Alexandra Whicher and Eloi Camprubi contributed equally to this work.

Electronic supplementary material The online version of this article (https://doi.org/10.1007/s11084-0189555-8) contains supplementary material, which is available to authorized users.

Nick Lane

nick.lane@ucl.ac.uk

1 Department of Genetics, Evolution and Environment, University College London, Darwin Building, Gower Street, London WC1E 6BT, UK 


\section{Introduction}

Phylogenetics and comparative physiology suggest that the earliest cells were autotrophic (Woese 1977; Baross and Hoffman 1985; Morowitz et al. 2000; Martin and Russell 2003; Smith and Morowitz 2004; Russell and Martin 2004; Braakman and Smith 2012; Weiss et al. 2016), living from relatively unreactive gases such as $\mathrm{H}_{2}$ and $\mathrm{CO}_{2}$, arguably via the acetyl CoA pathway (Russell and Martin 2004; Martin and Russell 2007; Sousa et al. 2013; Martin et al. 2014; Sojo et al. 2016). This pathway is the only $\mathrm{CO}_{2}$-fixation pathway found in both bacteria and archaea (Russell and Martin 2004; Martin and Russell 2007; Fuchs 2011). It is short, linear, and exergonic (Sousa et al. 2013; Martin et al. 2014) generating acetyl-CoA from $\mathrm{H}_{2}$ and $\mathrm{CO}_{2}$ via enzymes that contain multiple $\mathrm{Fe}(\mathrm{Ni}) \mathrm{S}$ clusters with structures similar to minerals such as greigite (Russell and Martin 2004; Kim et al. 2013; Harel et al. 2014; White et al. 2015). From acetyl CoA, a series of analogous hydrogenation and carbonylation reactions can produce carboxylic acids (Krebs cycle intermediates) from pyruvate to isocitrate (Camprubi et al. 2017; Muchowska et al. 2017). These are the precursors of amino acid, nucleotide, carbohydrate and lipid synthesis in essentially all living cells (Smith and Morowitz 2004, 2016; Martin and Russell 2007). But carboxylic acids are also tardily reactive as a starting point for these biosyntheses. Accordingly, metabolism is typically primed through formation of thioesters or phosphorylation by ATP (Srinivasan and Morowitz 2009). That poses a paradox at the origin of life as the synthesis of monomers such as nucleotides from $\mathrm{H}_{2}$ and $\mathrm{CO}_{2}$ via Krebs cycle intermediates has so far proved intractable under prebiotic conditions, despite its theoretical appeal.

In contrast, prebiotic syntheses of complex monomers such as activated nucleotides have been successful when starting from relatively reactive substrates such as cyanide, cyanoacetylene or formamide, typically energized by UV radiation (Powner et al. 2009; Saladino et al. 2012; Patel et al. 2015) or even proton irradiation (Saladino et al. 2015). While this is impressive synthetic chemistry, its relevance is ambiguous, as these syntheses do not resemble the biochemistry of extant cells in terms of substrates, catalysts, reaction pathways or energy coupling (Sojo et al. 2016; Keller et al. 2017a). Cyanide is not used by living cells as a source of either carbon or nitrogen for metabolism, nor is UV (or proton) radiation used as an energy source (Lane et al. 2010). Putatively prebiotic phosphorylating agents such as diamidophosphate are never used in modern cells and act by distinct mechanisms, primarily phosphorylating amino groups (Gibard et al. 2017). Similarly, meteoritic phosphate minerals such as schreibersite can phosphorylate nucleotides, but cannot be homologous to modern cells (Gull et al. 2015). If prebiotic chemistry really was so dissimilar to modern biochemistry, then at some point cells must have adopted radically different metabolic chemistry, starting with $\mathrm{CO}_{2}$ and promoting tardy reactions using ATP. If so, that exposes a severe and unexplained discontinuity at the origin of life. Whichever way the problem is seen, then, the emergence of biochemistry from geochemistry remains an unsolved problem.

Like all autotrophs, cells that use the acetyl CoA pathway depend on electrochemical ion gradients across membranes to drive $\mathrm{CO}_{2}$ fixation (Buckel and Thauer 2013). Specifically, methanogens use flavin-based electron bifurcation to generate a membrane potential (Kaster et al. 2011; Wagner et al. 2017) which is then used to reduce ferredoxin via the energyconverting [NiFe] hydrogenase Ech (Hedderich 2004; Thauer et al. 2008; Buckel and Thauer 2013). This is arguably the simplest and most direct use of membrane potential, hence could give insight into a prebiotic mechanism of $\mathrm{CO}_{2}$ fixation. We have argued that geologically sustained proton gradients could have modulated the reduction potential of both $\mathrm{H}_{2}$ and $\mathrm{CO}_{2}$ in alkaline hydrothermal systems, facilitating their reaction across semiconducting FeS barriers 
(Lane 2014; Herschy et al. 2014; Sojo et al. 2016) or fatty-acid membranes containing associated FeS crystals (West et al. 2017) to form small organics, notably Krebs cycle intermediates (Camprubi et al. 2017) in a manner analogous to Ech in methanogens (Sojo et al. 2016). Ancient alkaline hydrothermal systems provided $\mathrm{H}_{2}, \mathrm{CO}_{2}, \mathrm{FeS}$ barriers and geochemically sustained proton gradients (Russell et al. 1994; Russell and Hall 1997; Martin and Russell 2003, 2007; Sousa et al. 2013; Martin et al. 2014), conditions that hypothetically segue into $\mathrm{CO}_{2}$ reduction by $\mathrm{H}_{2}$ via a homologous proton-motive proto-Ech in the first cells (Sojo et al. 2016; West et al. 2017). Yet while vectorial prebiotic chemistry could feasibly form Krebs cycle intermediates (Camprubi et al. 2017), it is unlikely to have driven further intermediary metabolism in the absence of equivalents to acetyl CoA or ATP.

Both acetyl CoA and ATP are universally conserved across life, hence are most probably ancient (Morowitz et al. 2000; Smith and Morowitz 2004; Fuchs 2011; Martin et al. 2014). Nonetheless, both are complex molecules produced by genetically encoded enzymes, and so are unlikely to have driven the emergence of biochemistry at the origin of life. Plausible prebiotic precursors to acetyl CoA and ATP have been proposed to operate in a 'thioester' world (de Duve 1988, 1991; 1998; Sousa et al. 2013; Goldford et al. 2017). Prebiotic thioesters such as methyl thioacetate could arguably phosphorolyse to generate a phosphoester bond equivalent to that in ATP, as in the simple 2-carbon molecule acetyl phosphate, AcP (Ferry and House 2006; Martin et al. 2014; Sojo et al. 2016). This is analogous to modern cells, where acetyl-CoA is readily phosphorolysed to generate AcP in both bacteria and archaea (Decker et al. 1970; Thauer et al. 1977; Martin and Russell 2007). AcP then phosphorylates ADP to ATP (Ferry and House 2006; Schönheit et al. 2016) making it the fulcrum between thioester and phosphate metabolism (de Duve 1991). In terms of prebiotic chemistry, AcP could have been formed from simple thioesters such as methyl thioester, and then driven phosphorylation and condensation reactions in a similar fashion to ATP (Fig. 1) (de Duve 1991; Ferry and House 2006; Martin and Russell 2007), narrowing the gap between geochemistry and the origins of intermediary metabolism.

However, simple thioesters such as methyl thioacetate and putative ATP analogues like AcP have generally been considered to be too unstable to persist for long enough to drive prebiotic chemistry, especially at the high or low $\mathrm{pH}$ and hot temperatures found in hydrothermal systems (Barge et al. 2014; Chandru et al. 2016). AcP has long been overlooked experimentally as a prebiotic precursor to ATP, except in the synthesis of more stable (but less reactive) products such as pyrophosphate (Baltscheffsy and Baltscheffsky 1995; Kornberg et al. 1999; de Zwart et al. 2004; Barge et al. 2014). This perception stems largely from the 'heterotrophic' approach to prebiotic chemistry: stable organics are assumed to accumulate in a primordial soup or warm geothermal pond, perhaps with different precursors formed under distinct conditions before being brought together by some circumstance (Patel et al. 2015), all of which demands long-term stability. In contrast, autotrophic origins imply a continuous flux of inorganic substrates (e.g. $\mathrm{H}_{2}$ and $\mathrm{CO}_{2}$ ) in a specific environment, in which organic synthesis is driven by the continuous flux, and the rates of synthesis and breakdown or reaction at least balance over time (Branscomb and Russell 2013; Lane 2015; Barge et al. 2017). It does not matter if prebiotic thioesters or AcP react within minutes or hours so long as they are formed at a similar rate; indeed it is more parsimonious if they do, as they are then approaching the lability of biochemical intermediates.

Here we examine the synthesis and reactivity of AcP under mild alkaline hydrothermal conditions with this lability in mind. We show that AcP can indeed be formed readily under ambient or mild hydrothermal conditions, has an ideal balance between stability and reactivity, and is able to drive phosphorylation (but not condensation) reactions in water, making it a plausible and biologically meaningful link between prebiotic chemistry and monomer biochemistry. 

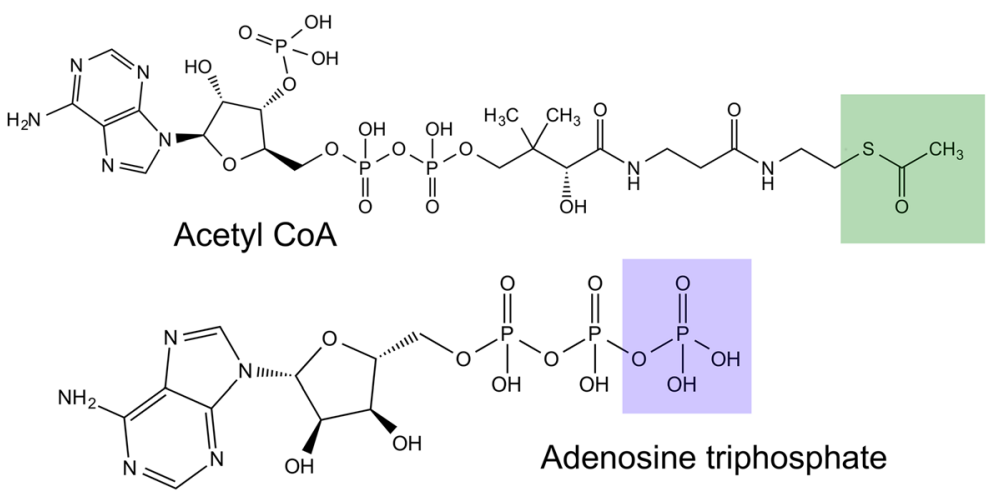<smiles>CC(=O)OP(=O)(O)O</smiles>

Acetyl phosphate

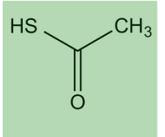

Thioacetic acid

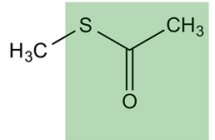

Methyl thioacetate

Fig. 1 Molecular structures of key biotic and prebiotic molecules. Acetyl CoA is the hub of metabolism in all six known pathways of carbon fixation. The 'business end' of the molecule is the reactive thioester group (green shaded section), which has prebiotic analogues in methyl thioacetate and thioacetic acid. Adenosine triphosphate (ATP) is the universally conserved energy currency in modern metabolism; acetyl phosphate (AcP) could have been a simple precursor, driving similar reactions. The blue shading highlights equivalent phosphate groups

\section{Results}

We have considered temperatures from 20 to $60^{\circ} \mathrm{C}$ and $\mathrm{pH}$ values from 6 to 12 , equivalent to the ranges found in alkaline hydrothermal vents (Russell et al. 1994, 2014; Martin et al. 2008; Nitschke and Russell 2009; Lane and Martin 2012). Such vents are composed of labyrinths of interconnected micropores with thin inorganic walls, which separate hydrothermal fluids ( $\mathrm{pH} 9$ 12) and ocean waters (Russell et al. 1994; Russell and Hall 1997; Kelley et al. 2005). The oceans were probably mildly acidic (pH 5-7) in the Hadean, as $\mathrm{CO}_{2}$ levels were higher (Pinti 2005; Arndt and Nisbet 2012). Mixing within the vent is driven by convection and thermal diffusion (Braun and Libchaber 2002; Baaske et al. 2007; Mast and Braun 2010; Mast et al. 2013; Herschy et al. 2014; Kreysing et al. 2015) which is important for three reasons. First, conditions for organic synthesis are not necessarily warm and strongly alkaline, but could equally be cool and neutral $\mathrm{pH}$, or even mildly acidic. Second, convective cycling means that products formed in cool, neutral conditions can cycle through warm, alkaline conditions, potentially driving other reactions, including simple hydrolysis. Third, thermal cycling can concentrate small organics such as nucleotides by at least 5000-fold via thermophoresis (Baaske et al. 2007; Mast and Braun 2010; Mast et al. 2013; Herschy et al. 2014; Kreysing et al. 2015) converting low yields (e.g. $\mu$ M range) into high concentrations (e.g. high $\mathrm{mM}$ range) that favor molecular interactions and ultimately the polymerization of amino acids and nucleotides (Mast et al. 2013; Herschy et al. 2014). Such extreme concentration by thermophoresis partially justifies the relatively high concentrations of reagents used in this paper (see Discussion).

We expected to synthesise AcP by phosphorolysing methyl thioacetate $\left(\mathrm{CH}_{3} \mathrm{COSCH}_{3}\right)$. This simple prebiotic thioester has been argued to have properties equivalent to acetyl CoA (de Duve 1988, 1991; Martin and Russell 2007; Lane and Martin 2012), and has indeed been 
formed under hydrothermal conditions from $\mathrm{CO}$ and $\mathrm{CH}_{3} \mathrm{SH}$ alone (Huber and Wächtershäuser 1997). In fact, we did not detect any AcP from $\mathrm{CH}_{3} \mathrm{COSCH}_{3}$ in the presence of $20 \mathrm{mM} \mathrm{Na}_{2} \mathrm{HPO}_{4}$, but rather generated yields of up to $2 \%$ within $1-2 \mathrm{~h}$ from the even simpler precursor thioacetate $\left(\mathrm{CH}_{3} \mathrm{COSH}\right)$ (Figs. 1 and 2). The yield depended on $\mathrm{pH}$, temperature, and ions present. Under mildly acidic conditions and cooler temperatures $\left(\mathrm{pH} 6,20{ }^{\circ} \mathrm{C}\right.$ ), equimolar mixtures of $\mathrm{Ca}^{2+}$ and $\mathrm{Mg}^{2+}$ ions promoted synthesis of AcP, compared with no ions (Fig. 2a). Under more alkaline conditions, $\mathrm{Ca}^{2+}$ and $\mathrm{Mg}^{2+}$ ions lowered AcP synthesis, because $\mathrm{Ca}^{2+}$ precipitated out some phosphate as apatite, so less was available for AcP formation (Fig. $2 \mathrm{~b}$ and c; data for $\mathrm{Ca}^{2+}$ alone are not shown, as nanoparticles interfered with NMR measurements). AcP was not formed at all at $\mathrm{pH} \mathrm{11,} \mathrm{even} \mathrm{in} \mathrm{the} \mathrm{absence} \mathrm{of} \mathrm{ions}$ (Online resource 1). In contrast, $\mathrm{Mg}^{2+}$ alone precipitated relatively little phosphate below $\mathrm{pH} 11$, and doubled yields of AcP under neutral or mildly alkaline conditions, presumably promoting synthesis relative to breakdown of AcP (Fig. 2d-f). These data foreshadow the close association of $\mathrm{Mg}^{2+}$ ions with AcP, ATP and nucleotides, and the exclusion of $\mathrm{Ca}^{2+}$ ions from modern cells. Synthesis under anaerobic conditions did not affect the yield of AcP, indicating that thioacetate is equally reactive in the absence of oxygen (Online resource 2). Addition of $\mathrm{Fe}^{2+}$ also had little effect on AcP synthesis when the experiments were repeated under anoxic conditions (Online resource 2).

At ambient temperatures and non-extreme $\mathrm{pH}$, AcP is reasonably stable, as previously reported by others (Koshland 1952; Etaix and Buvet 1975) with $20 \%$ hydrolysed over $5 \mathrm{~h}$ at $20{ }^{\circ} \mathrm{C}$ under the range of $\mathrm{pH}$ conditions tested (Fig. 3a). The rate of hydrolysis depends strongly on temperature, with AcP completely hydrolysed within $3-5 \mathrm{~h}$ at $50{ }^{\circ} \mathrm{C}$, and within $90 \mathrm{~min}$ at $60{ }^{\circ} \mathrm{C}$ (Fig. 3a). In contrast, $\mathrm{pH}$ had little effect at any temperature (Fig. 3a). The presence of $\mathrm{Mg}^{2+}$ (Fig. 3b) and $\mathrm{Ca}^{2+}$ (Fig. 3c) ions also had little effect, slightly speeding the initial rate of hydrolysis at both $20^{\circ} \mathrm{C}$ and $50{ }^{\circ} \mathrm{C}$, as reported previously for concentrated salt solutions by Di Sabato and Jencks (1961b), but not changing the overall proportion hydrolysed over $5 \mathrm{~h}$ (Fig. $3 \mathrm{~b}$ and c). However, at higher temperatures $\left(50^{\circ} \mathrm{C}\right)$, the balance between AcP formation and hydrolysis shifted markedly towards hydrolysis (Fig. $2 \mathrm{~g}-\mathrm{i}$ ). Although the initial rate of synthesis was slightly faster, AcP was almost completely hydrolysed within $3 \mathrm{~h}$, especially under mildly alkaline conditions ( $\mathrm{pH} \mathrm{8}$; Fig. 2i). In the vent setting, therefore, AcP synthesis should occur mostly in cooler, more neutral regions, precisely the regions where organics tend to accumulate by thermophoresis (Baaske et al. 2007; Herschy et al. 2014), and should be stable under aqueous neutral to alkaline conditions over at least several hours.

Once formed, AcP can indeed phosphorylate substrates. We considered first whether AcP could phosphorylate nucleotide precursors under a range of alkaline hydrothermal conditions. Given their symbolic relevance to RNA synthesis, we specifically examined the synthesis of ribose-5-phosphate (R5P) from ribose, adenosine monophosphate (AMP) from adenosine, and ATP from ADP. For R5P, the overall yield (relative to ribose) was modest ( $2 \%$ ) but the rate of synthesis was rapid, with $>500 \mu \mathrm{M}$ R5P formed within $8 \mathrm{~min}$ at $20^{\circ} \mathrm{C}$ in the absence of $\mathrm{Ca}^{2+}$ and $\mathrm{Mg}^{2+}$ ions, and concentrations peaking at $\sim 2500 \mu \mathrm{M}$ after $120 \mathrm{~h}$ (Fig. 4a, c-d). R5P is surprisingly stable at $20^{\circ} \mathrm{C}$, with no loss of yield over 5 days (Fig. 4 a inset). The rate of synthesis of $\mathrm{R} 5 \mathrm{P}$ was even faster at $50{ }^{\circ} \mathrm{C}$, with concentrations reaching $\sim 1500 \mu \mathrm{M}$ within $8 \mathrm{~min}$ and $\sim 2300 \mu \mathrm{M}$ after $2 \mathrm{~h}$, giving a similar total yield (Fig. $4 \mathrm{~b}$ ). However, $\sim 20 \%$ of this yield was lost by hydrolysis over the following 5 days at $50{ }^{\circ} \mathrm{C}$ (Fig. $4 \mathrm{~b}$ inset). The apparent stability of R5P to hydrolysis over 5 days, even at $50{ }^{\circ} \mathrm{C}$, was unexpected, so we measured the stability of commercial R5P under equivalent $\mathrm{pH}$ and temperature conditions; we confirmed that $\mathrm{R} 5 \mathrm{P}$ is indeed relatively stable to hydrolysis under mild hydrothermal conditions (Online resource 3). 


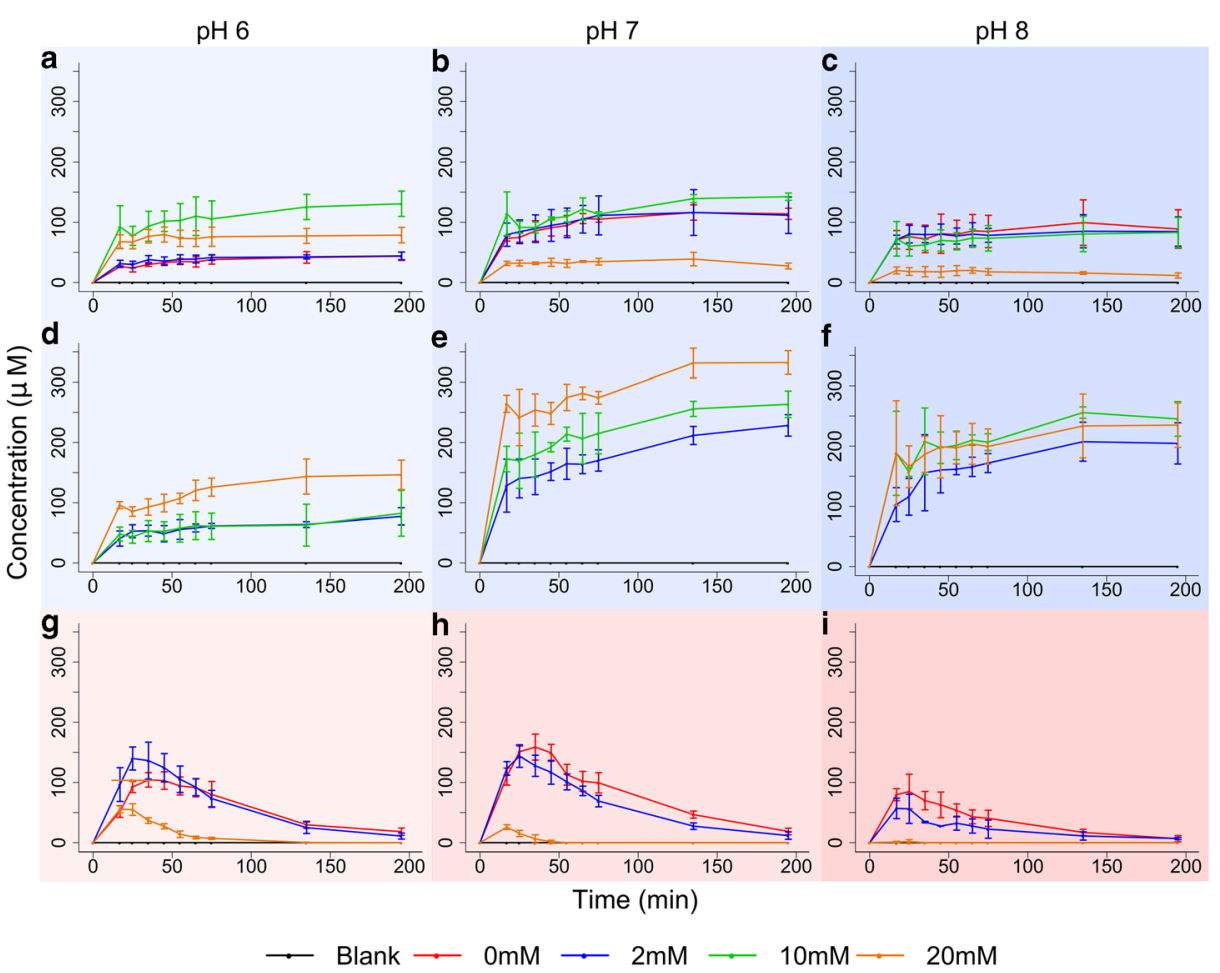

Fig. 2 Synthesis of AcP from orthophosphate and thioacetate. a-c AcP synthesis at pH 6, 7 and 8 , respectively, with varying equimolar concentrations of $\mathrm{Ca}^{2+}$ and $\mathrm{Mg}^{2+}$ ions at $20^{\circ} \mathrm{C}$. $\mathbf{d}-\mathbf{f}$ varying concentrations of $\mathrm{Mg}^{2+}$ ions alone. $\mathbf{g}-\mathbf{i}$ varying concentrations of both $\mathrm{Ca}^{2+}$ and $\mathrm{Mg}^{2+}$ ions at $50{ }^{\circ} \mathrm{C} . N=3 \pm \mathrm{SD}$

While $\mathrm{pH}$ had little effect, synthesis of R5P was slightly lower at $\mathrm{pH} 11$ (Fig. 4a,b), reflecting the formation of tetra-acetylated ribose at $\mathrm{pH} 11$ alone (Online resource 4). This corresponds to the known $\mathrm{p} K_{\mathrm{a}}$ of the $\mathrm{OH}$ groups of ribose, which is $\sim 11.8$ (Sen et al. 2014) hence these are acetylated only at quite strongly alkaline $\mathrm{pH}$. The presence of other ions lowered the rate of R5P synthesis and tended to increase its rate of hydrolysis at $50{ }^{\circ} \mathrm{C}$ (Online resource 5 ). $\mathrm{Ca}^{2+}$ ions $(0.15 \mathrm{M})$ halved the initial rate of synthesis but subsequently had a limited effect on hydrolysis. In contrast, $\mathrm{Mg}^{2+}$ ions barely effected the initial rate of synthesis but tended to promote hydrolysis, with $\sim 40 \%$ loss over $48 \mathrm{~h}$ (Online resource 5). Again this points to the differing roles of $\mathrm{Mg}^{2+}$ and $\mathrm{Ca}^{2+}$ in the cell, whereby $\mathrm{Mg}^{2+}$ promotes both the formation and reactivity of phosphorylated intermediates. Borate ions have previously been claimed to stabilise ribose (Ricardo et al. 2004) potentially favoring phosphorylation to ribose-5-phosphate (Mellersh and Smith 2010) but had little effect in our hands (Online resource 5).

The phosphorylation of adenosine to AMP by AcP was markedly slower, taking several hours even at $50{ }^{\circ} \mathrm{C}$ (Fig. 4e-h), but ultimately achieving a similar yield (relative to adenosine) of $\sim 2 \%$. These differences may reflect steric or chemical hindrance by the nucleobase, or the reaction conditions, which differed due to the limited solubility of adenosine (maximum solubility at $20{ }^{\circ} \mathrm{C} \sim 10 \mathrm{mM}$ ). Again, the concentration of AMP formed at $\mathrm{pH} 11$ was slightly lower; but in general the $\mathrm{pH}$ had little effect on phosphorylation in the case of either R5P or AMP. Nor did the presence or absence of $\mathrm{Mg}^{2+}$ or $\mathrm{Fe}^{2+}$ ions under anaerobic or aerobic conditions (Online resource 6). Although the rate of reaction was slower in this case compared 
a

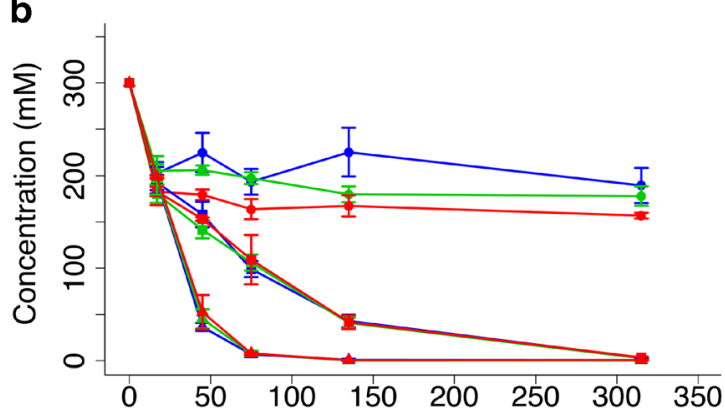

C
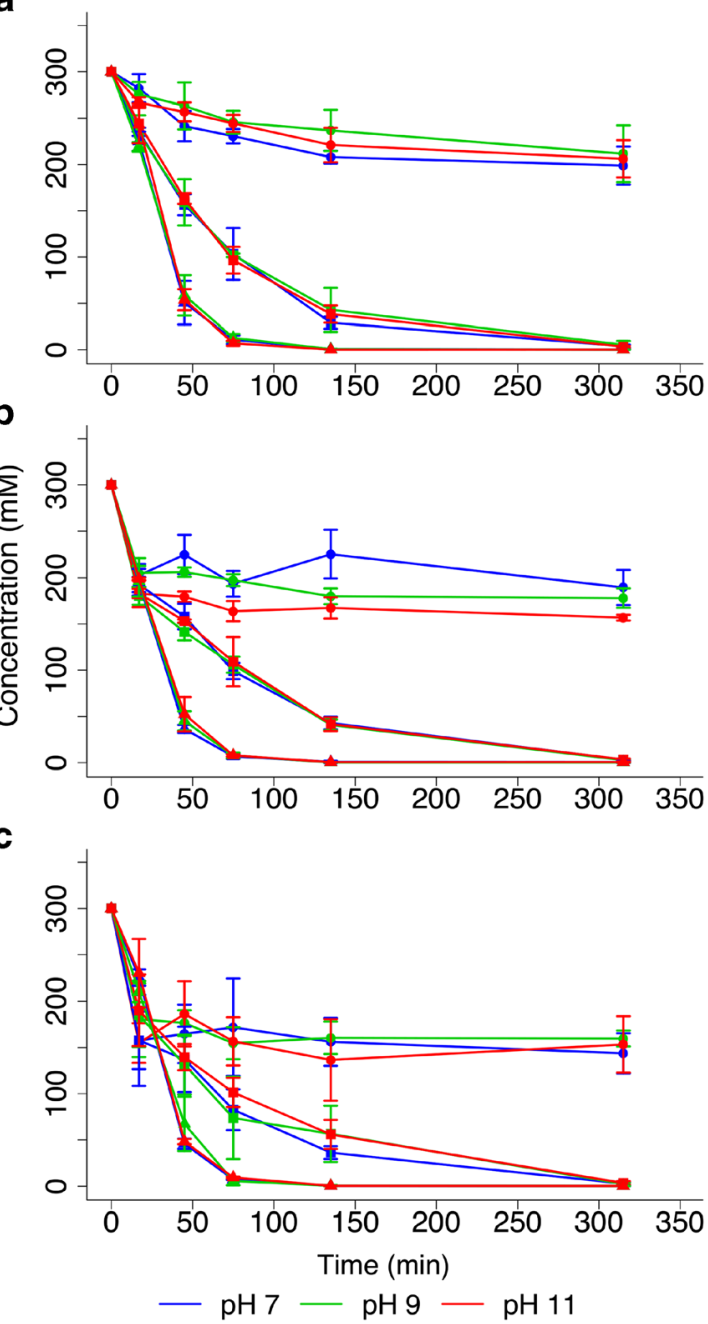

Fig. 3 Stability of AcP depending on $\mathbf{p H}$, temperature and ions. Degradation profile for AcP over $5 \mathrm{~h}$ with and without ions at $\mathrm{pH} \mathrm{7,9}$ and 11 , stored at $20^{\circ} \mathrm{C}$ (circles), $50{ }^{\circ} \mathrm{C}$ (squares) and $60{ }^{\circ} \mathrm{C}$ (triangles). a no ions added, b with $20 \mathrm{mM} \mathrm{Mg}^{2+}$ ions added, $\mathbf{c}$ with $20 \mathrm{mM} \mathrm{Ca}^{2+}$ ions added. $\mathrm{N}=3 \pm \mathrm{SD}$

with R5P, all these phosphorylations took place within minutes to hours, rather than days to weeks as commonly reported (Lohrmann and Orgel 1968; Chung et al. 1971). These relatively rapid reaction rates are more commensurate with cellular biochemistry, as catalysed by enzymes, than with much slower geological processes, and so offer a first step towards the far-from-equilibrium dynamics of living cells.

$\mathrm{AcP}$ can also phosphorylate ADP to ATP in water, but we were unable to quantify the ATP yields using ${ }^{31} \mathrm{P}-\mathrm{NMR}$, as the concentrations were close to the limits of detection of our instrument (Fig. 5). We could not detect ATP over $24 \mathrm{~h}$ at $20^{\circ} \mathrm{C}$, but we did detect ATP synthesis after $1-5 \mathrm{~h}$ by both ${ }^{31} \mathrm{P}-\mathrm{NMR}$ (Fig. 5) and HPLC (Online resource 7) at $50{ }^{\circ} \mathrm{C}$, again suggesting reactivity over time periods of minutes to hours. We plan to develop more sensitive HPLC analyses for ATP synthesis in future, so simply report its successful synthesis here. Our findings corroborate those of 

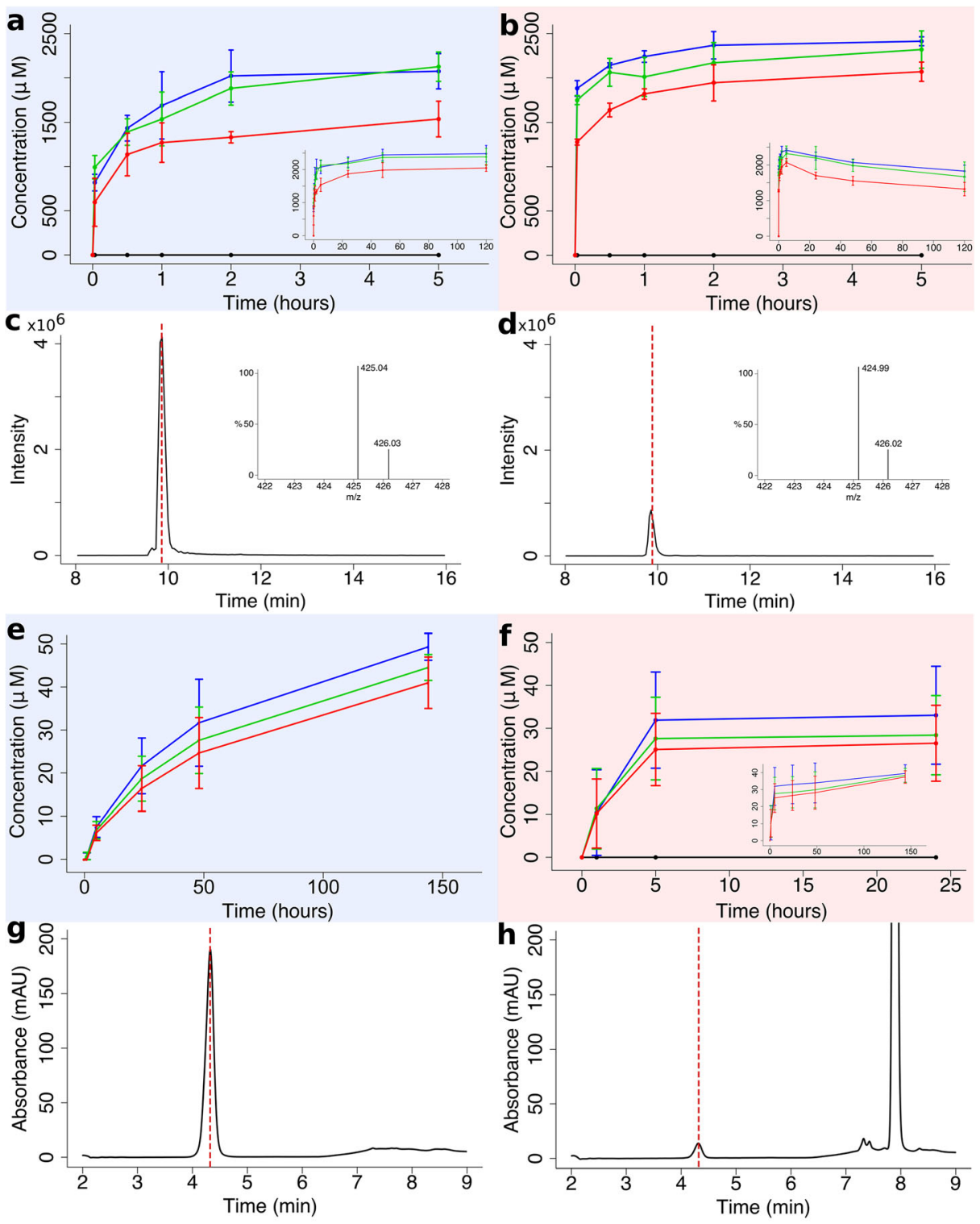

\section{$\rightarrow \mathrm{pH} 7 \rightarrow \mathrm{pH} 9 \rightarrow \mathrm{pH} 11$}

Fig. 4 Phosphorylation of ribose and adenosine by AcP. a-b Synthesis of ribose-5-phosphate from D-ribose and $\mathrm{AcP}$ at $\mathrm{pH} 7,9$ and 11 at: $\mathbf{a} 20^{\circ} \mathrm{C}$ and (b) $50{ }^{\circ} \mathrm{C}$. Graph inserts show full reaction profile over $120 \mathrm{~h}$. c-d LCMS chromatogram for derivatised ribose-5-phosphate (monoisotopic mass: $425.14 \mathrm{~m} / \mathrm{z}$ ): c standard and (d) experimental sample. Graph inserts show mass spectra for each peak. e-f Phosphorylation of adenosine to adenosine monophosphate (AMP) by $\mathrm{AcP}$ at $\mathrm{pH} 7,9$ and 11: e $20^{\circ} \mathrm{C}$ and (f) $50{ }^{\circ} \mathrm{C}$. Graph insert shows full reaction profile over $144 \mathrm{~h}$. $\mathbf{g}-\mathbf{h}$ HPLC-UV chromatogram for detection of AMP at $4.3 \mathrm{~min}$ at $254 \mathrm{~nm} \mathrm{UV}$ wavelength; $\mathbf{g}$ standard and (h) experimental sample. The large peak at $7.9 \mathrm{~min}$ is adenosine. $\mathrm{N}=3 \pm \mathrm{SD}$

Kitani et al. (1995) who reported the synthesis of ATP from ADP using AcP, especially when catalysed by $\mathrm{Fe}^{3+}$. Unlike Kitani et al. we found higher yields at higher temperatures. 


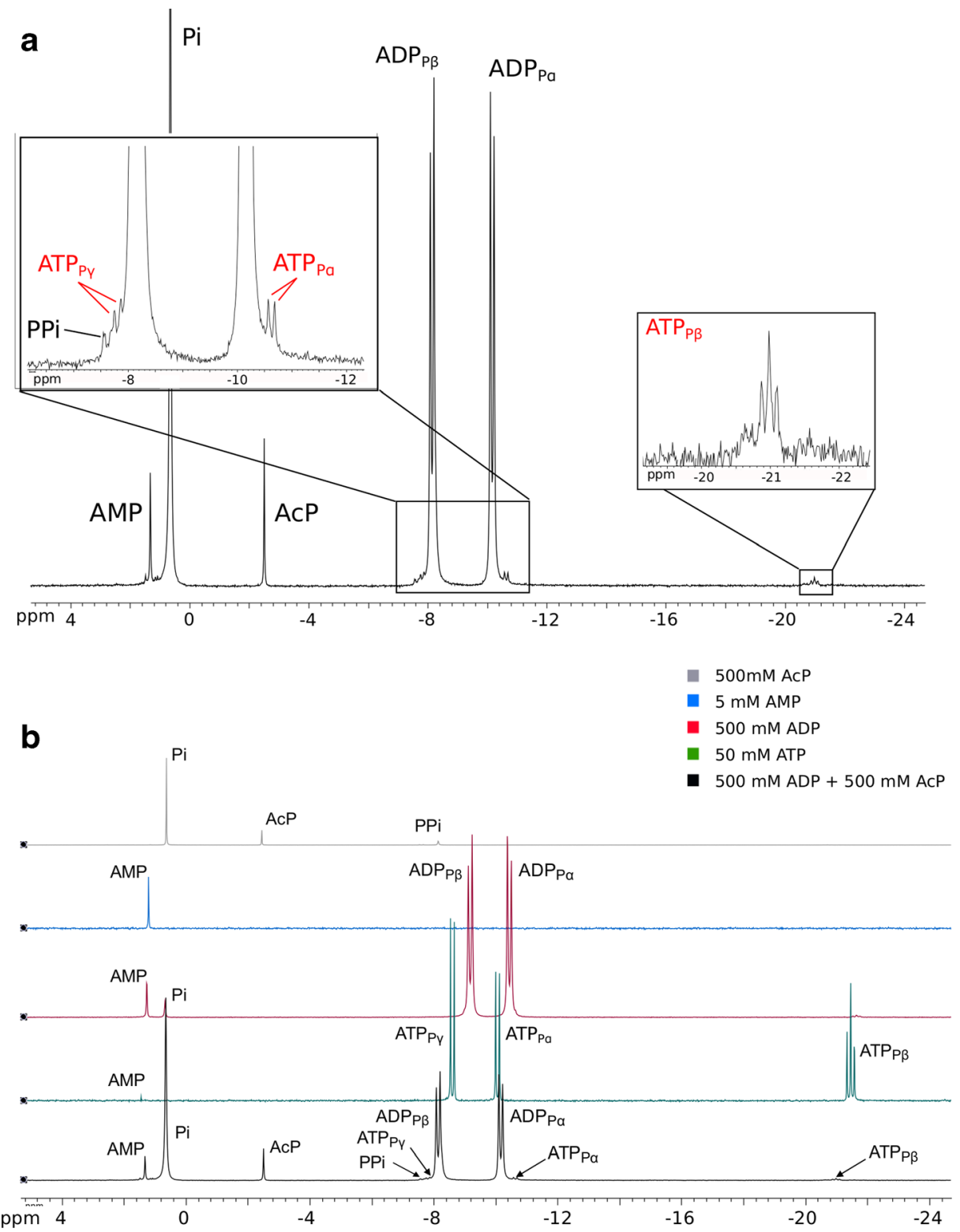

Fig. 5 Phosphorylation of ADP by AcP. a ${ }^{31}$ P-NMR spectrum of the phosphorylation of ADP by AcP at $50^{\circ} \mathrm{C}$ and pH 5.5 after $2 \mathrm{~h}$, yielding ATP. All peaks labelled for clarity. Graph inserts show zoomed in areas of ATP signal. b ${ }^{31} \mathrm{P}-\mathrm{NMR}$ spectra of the phosphorylation of ADP by AcP, compared with commercial ATP, commercial ADP, commercial AMP, and commercial AcP. Small $\mathrm{pH}$ differences account for the imperfect alignment of the peaks between -8 and $-10 \mathrm{ppm}$

AcP did not polymerise either amino acids or nucleotides in water. Our studies here were limited in that we did not consider polymerization on mineral surfaces or at lower water activity, but only in aqueous solution. Nonetheless, we had hoped to detect short polymers as a first step. We attempted to polymerize glycine in water but were unable to detect any diglycine, 
diketopiperazine, or any other short polymer; instead we corroborated the findings of others (Di Sabato and Jencks 1961a), that AcP efficiently acetylates the amino group of glycine to form N-acetyl glycine (NAG), especially under alkaline conditions. Diglycine forms two peaks on ${ }^{1} \mathrm{H}-\mathrm{NMR}$ (Fig. 6) whereas the condensed form of diglycine, diketopiperazine (DKP) forms a single peak. Under alkaline conditions ( $\mathrm{pH}$ 9-12) we detected two peaks at around $3.7 \mathrm{ppm}$ and $2 \mathrm{ppm}$ (with the exact chemical shift varying slightly with $\mathrm{pH}$ ) within minutes of adding AcP to glycine in solution. These peaks corresponded to the formation of NAG (Fig. 6a). This interpretation was confirmed by the behavior of NAG by ${ }^{1} \mathrm{H}-\mathrm{NMR}$ under more acidic conditions (Fig. 6b and Online resource 8). At pH 7 and below, NAG still forms two peaks, but the peak at $3.7 \mathrm{ppm}$ now splits into a doublet. The splitting of the $\mathrm{H} 2-\mathrm{C}$ protons at low $\mathrm{pH}$ relates to their interaction with the proton on the neighbouring N. This H-N proton exchanges with protons in the solvent at a rate that depends on $\mathrm{pH}$. At low $\mathrm{pH}$ the rate of exchange of the $\mathrm{H}-\mathrm{N}$ proton is lower than the speed at which that proton affects the $\mathrm{H} 2-\mathrm{C}$ protons (by shielding and un-shielding), so the $\mathrm{H} 2-\mathrm{C}$ signal splits. This $\mathrm{pH}$-dependent peak splitting at $3.7 \mathrm{ppm}$ is diagnostic of NAG and confirms that this was the major product formed, rather than diglycine or DKP. We found an $80 \%$ yield (relative to glycine) after $24 \mathrm{~h}$ at an initial $\mathrm{pH} 12$ (with $\sim 70 \%$ yield after $1 \mathrm{~h}$ ) falling to $<40 \%$ yield at an initial $\mathrm{pH} 7-9$ after $24 \mathrm{~h}$ (Fig. $6 \mathrm{c}$ ).

AcP did not promote the polymerization of AMP in water, but we did detect aggregated stacks of up to 7 monomers, which have been suggested to favour polymerisation, at least of cyclic nucleotides through a base catalysed 'click-type' mechanism (Costanzo et al. 2009; Costanzo et al. 2012). We examined the behaviour of non-cyclic AMP, as others have successfully polymerized imidazole-activated AMP in water on clay catalysts (Burcar et al. 2015). Aggregates

a



100mM NAG pH12

100mM DKP pH12

100mM DiGly pH12

$0.5 \mathrm{M} \mathrm{ACP} \mathrm{pH} 12$

- 0.5M Gly + 0.5M ACP pH12

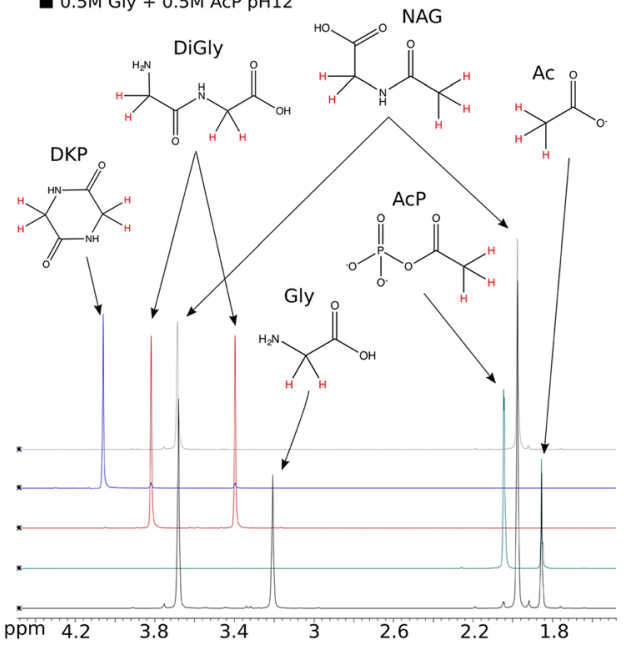

b

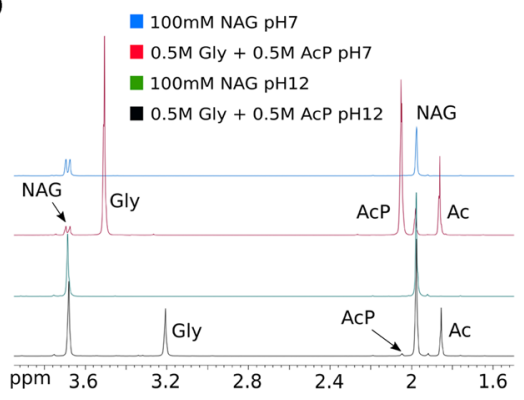

C

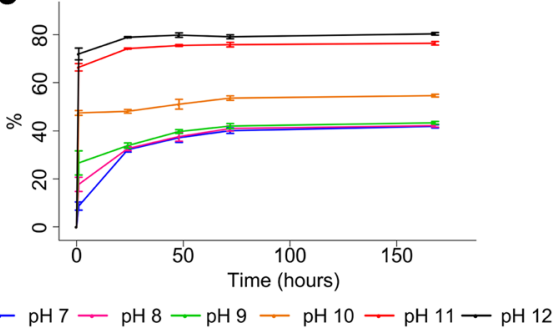

Fig. 6 Acetylation of glycine in water by AcP. a ${ }^{1} \mathrm{H}-\mathrm{NMR}$ spectra of acetylation of glycine to N-acetylglycine (NAG) by AcP at $20^{\circ} \mathrm{C}$ and $\mathrm{pH} 12$ after $2 \mathrm{~h}$, compared with AcP, diglycine, diketopiperazine (DKP), and NAG; all commercial standards were titrated to $\mathrm{pH} 12$. Molecular structures highlighting the protons giving rise to each spectroscopic peak are added for clarity. $\mathbf{b}{ }^{1} \mathrm{H}-\mathrm{NMR}$ spectra of the acetylation of glycine to NAG by AcP at $\mathrm{pH} 12$ and at $\mathrm{pH} 7$ compared with the spectra of commercial NAG at both $\mathrm{pH} 12$ and pH 7. c Acetylation of glycine by $\mathrm{AcP}$ at $20{ }^{\circ} \mathrm{C}$ at different initial $\mathrm{pH}$ values over $168 \mathrm{~h} . \mathrm{N}=3 \pm \mathrm{SD}$ 
a

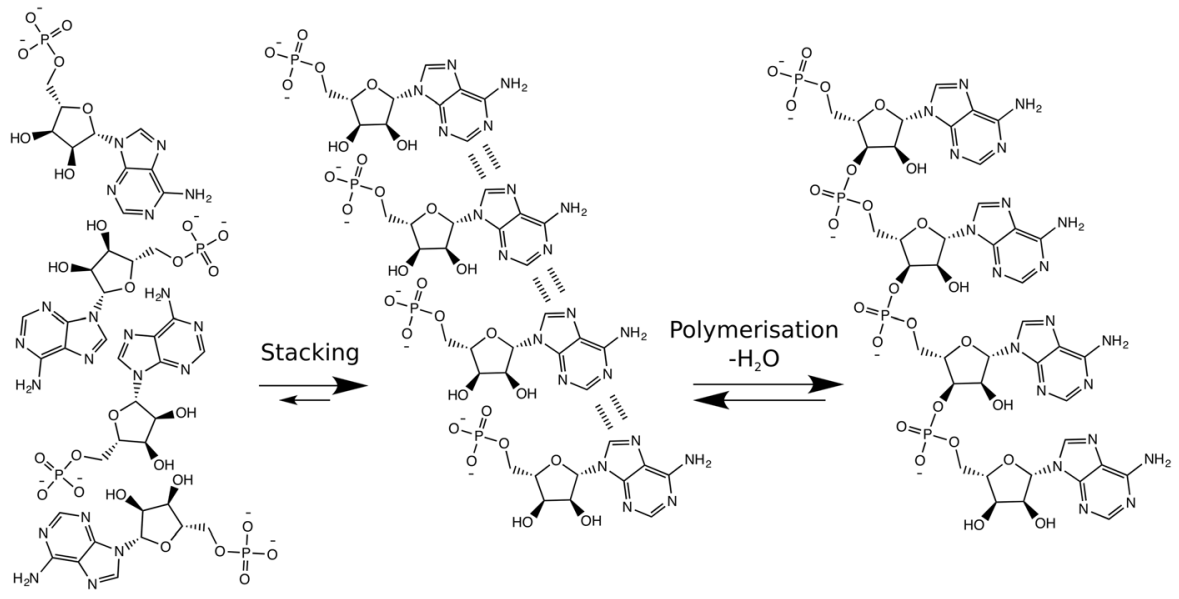

b

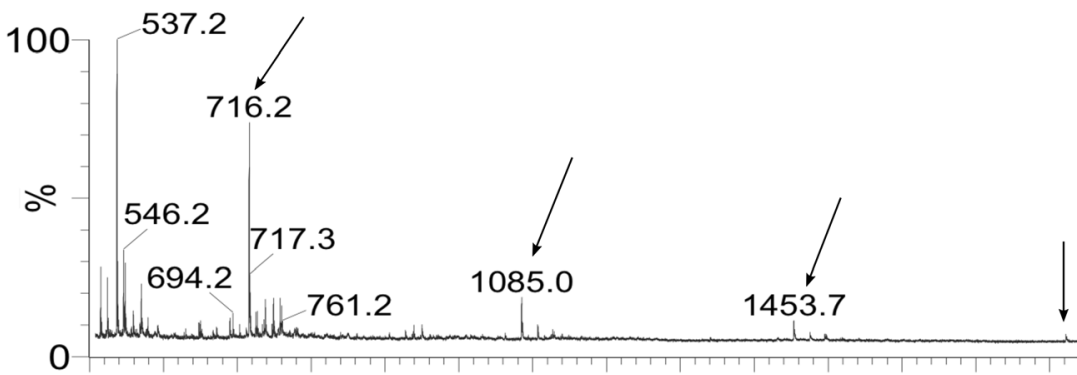

Fig. 7 AMP stacking. a Diagram showing stacking (middle) and polymerisation (right) of AMP monomers. Stacking is energetically favoured in water due to nucleobase interactions, and even more so when dissolved cations balance the negative charges of AMP. b MALDI mass spectrum of the products of the reaction of AMP $(3 \mathrm{mM})$ and $\mathrm{AcP}(450 \mathrm{mM})$, at $\mathrm{pH} 5$ and after $24 \mathrm{~h}$ of incubation at $20{ }^{\circ} \mathrm{C}$. Other incubation conditions (temperature, $\mathrm{pH}$, time) resulted in similar spectra. $716.2 \mathrm{~m} / \mathrm{z}$ peak corresponds to $2 \mathrm{xAMP}$ (AMP $=347.22 \mathrm{~m} /$ $\mathrm{z})+\mathrm{Na}^{+} ; 1085.0 \mathrm{~m} / \mathrm{z}$ peak corresponds to $3 \times \mathrm{AMP}+\mathrm{K}^{+}+\mathrm{Li}^{+} ; 1453.7 \mathrm{~m} / \mathrm{z}$ peak corresponds to $4 \times \mathrm{AMP}^{+} \mathrm{Na}^{+}+$ $\mathrm{K}^{+}+\mathrm{Li}^{+} ; 1824.1 \mathrm{~m} / \mathrm{z}$ peak corresponds to $5 \mathrm{xAMP}+2 \mathrm{xNa}^{+}+\mathrm{K}^{+}+\mathrm{Li}^{+}$

are easily mistaken for polymers (Burcar et al. 2013), but differ from them in that one waterequivalent is lost for each monomer that is added to a polymer, due to the condensation necessary to generate the new covalent bond (Fig. 7a). Using MALDI-TOF, the ion fragments indicative of AMP polymerisation are therefore: 2-mer $(675.44 \mathrm{~m} / \mathrm{z}), 3-\operatorname{mer}(1004.66 \mathrm{~m} / \mathrm{z}), 4-\operatorname{mer}(1333.88 \mathrm{~m} /$ $\mathrm{z}$ ) and successive additions of $329.22 \mathrm{~m} / \mathrm{z}$, corresponding to an AMP residue (AMP $(347.22 \mathrm{~m} / \mathrm{z}$ ) $-\mathrm{H}_{2} \mathrm{O}(18.01 \mathrm{~m} / \mathrm{z})$ incorporated into the growing RNA polymer.

We initially thought that we had produced AMP polymers, as aggregates were only formed upon the addition of AcP. However, the peaks detected were at 716.3, 1085.1, 1453.4, 1821.74, 2190.8, 2558,37 m/z, marked by arrows (Fig. 7b). These do not correspond to AMP polymers, but could reflect the presence of adducts of nucleotide aggregates with counter-ions. We therefore ran experiments with alternative cations $\mathrm{K}^{+}$and $\mathrm{Li}^{+}$replacing $\mathrm{Na}^{+}$as a counter-ion to AcP. Online resource 9 shows that the peak at $1085.1 \mathrm{~m} / \mathrm{z}$ appeared only when the original AcP solution (which contained a high $\mathrm{Na}^{+}$concentration from the preparation protocol) was added. The peaks detected varied with the most common cation 
present (generating different aggregates) and not as a result of polymerisation. So the addition of AcP promoted AMP aggregation in our first experiments because the counter-ion, $\mathrm{Na}^{+}$, stabilizes the formation of aggregated stacks containing up to 7 AMP monomers. While these findings were disappointing, it remains possible that AcP could promote nucleotide polymerization on mineral surfaces or at lower water activity.

\section{Discussion}

We show that $\mathrm{AcP}$ is formed at modest $(2 \%)$ yields within minutes under ambient conditions (neutral $\mathrm{pH}$ and $20^{\circ} \mathrm{C}$ ) and mild hydrothermal $\left(\mathrm{pH} 8,50^{\circ} \mathrm{C}\right.$ ) conditions, from the simple 2-carbon precursor thioacetate (Fig. 2). We did not detect the formation of AcP from the simple thioester methyl thioacetate under any of the conditions tested. While most theoretical work (de Duve 1991; Martin and Russell 2007) has considered methyl thioacetate as a prebiotic equivalent to acetyl $\mathrm{CoA}$, thioacetate has also been synthesised from $\mathrm{CO}$ and $\mathrm{CH}_{3} \mathrm{SH}$ under mild hydrothermal conditions (Huber and Wächtershäuser 1997). Being even simpler, thioacetate is arguably a more plausible prebiotic precursor, if not a thioester. Once formed, AcP exhibits an ideal poise between stability and reactivity: it is stable over $>5 \mathrm{~h}$ under ambient conditions, even at $\mathrm{pH} 11$ and in the presence of $\mathrm{Mg}^{2+}$ and $\mathrm{Ca}^{2+}$ ions (Fig. 3). Earlier work showed that AcP is hydrolysed much more rapidly above $\mathrm{pH} 11$ (Koshland 1952; Etaix and Buvet 1975), but those conditions would be rare even in alkaline hydrothermal systems (Kelley et al. 2001; 2005) and we did not study them here. AcP is less stable at warmer temperatures: it is completely hydrolysed over $3-5 \mathrm{~h}$ at $50{ }^{\circ} \mathrm{C}$, and within 90 min at $60{ }^{\circ} \mathrm{C}$ (Fig. 3). AcP does indeed act as an ATP mimetic, phosphorylating several intermediates in nucleotide synthesis, in water, over minutes to hours: ribose to ribose-5phosphate (Fig. 4), adenosine to AMP (Fig. 4), and ADP to ATP (Fig. 5). But AcP did not promote the polymerization of either amino acids (glycine; Fig. 6) or nucleotides (AMP; Fig. 7) in aqueous solution. Instead, it tended to acetylate the amino group of amino acids (Fig. 6), especially at more alkaline $\mathrm{pH}$, as reported by others (Di Sabato and Jencks 1961a). AcP can also acetylate all four hydroxide groups on ribose at strongly alkaline $\mathrm{pH}$ (11), albeit in quite low amounts (Online resource 4). Its tendency to acetylate amino groups could partially explain why $\mathrm{AcP}$ is used less commonly than ATP to catalyse phosphorylation reactions in modern cells, and indeed in archaea AcP remains bound to the active site of acetyl CoA synthetase (Bräsen et al. 2008; Schönheit et al. 2016).

While the yields of phosphorylated products were generally low $(\sim 2 \%)$ we do not consider that to be a problem; rather the reverse. As argued by de Duve (2005), the 'only scientifically plausible' explanation for the emergence of biological catalysts, whether ribozymes or enzymes, is selection. The first biological catalysts must have been selected because they enhanced flux through proto-metabolic pathways. These proto-metabolic pathways presumably had much the same substrates and products, and probably many equivalent intermediates, as later genetically encoded pathways (Copley et al. 2007; Martin et al. 2014; Sojo et al. 2016; Keller et al. 2017a). Tardy reactions should have been promoted by mechanisms equivalent to those still observed in modern cells, such as phosphorylation. That is what we did find. AcP is formed under mild prebiotic conditions; it is capable of phosphorylating biologically meaningful molecules, including ADP to ATP; and it is still used by cells today, critically as the fulcrum between thioester and phosphate metabolism (de Duve 1991; Ferry and House 2006; Schönheit et al. 2016). If metabolism did indeed emerge through selection, then low yields of intermediates and products would be expected to form in water in the absence of catalysts. 
Work on prebiotic forms of glycolysis and the pentose phosphate pathway (Keller et al. 2014), TCA cycle (Keller et al. 2017b) and gluconeogenesis (Messner et al. 2017) suggests that the intermediates do indeed form spontaneously under prebiotic conditions. These intermediates are necessarily relatively reactive, or they would accumulate and could not be part of metabolic networks (Smith and Morowitz 2004; Keller et al. 2017a).

The first steps of catalysis should be promoted by ions or mineral clusters equivalent to the cofactors of modern proteins. Simple ions in solution should improve yields slightly. Accordingly, we found that $\mathrm{Mg}^{2+}$ promoted the synthesis of $\mathrm{AcP}$ from thioacetate relative to other ions. That is important because $\mathrm{Mg}^{2+}$ is unusual in being able to complex with two phosphate groups (Holm 2012); it is still required in cells today to maintain the structure of RNA and enzymes, as well as the activity of phosphorylated molecules, including ATP. Chelation of ions or small mineral crystals (such as FeS clusters) by amino acids or short polypeptides should enhance catalysis further, as these complexes ought to mimic the active site of enzymes for reasons of physical chemistry, increasing yields further (Milner-White and Russell 2005, 2011; Copley et al. 2007; Nitschke et al. 2013; West et al. 2017). Ultimately, genetically encoded ribozymes or enzymes would increase yields considerably more. In other words, the explicit prediction of a selectionist approach to the origin of life is that the yields of prebiotic reactions should be low in the absence of organic catalysts in water. From this perspective, the synthetic chemists' preoccupation with high prebiotic yields of specific products is misguided.

The fact that AcP did not drive the condensation of amino acids or nucleotides, even to a limited degree, was disappointing, but possibly significant. We had hoped that short polymers would form spontaneously in water in the presence of AcP. In the case of glycine, we generated high yields (up to 80\%) of N-acetyl glycine, as reported by others (Di Sabato and Jencks 1961a). NAG did not react any further, although acetylation of amino groups can promote the formation of short peptides in the presence of amino acid esters, AMP, a carbodiimide and 1-ethylimidazole, as acetylation of the amino group facilitates reaction of the carboxylic acid group instead (Jauker et al. 2015; Griesser et al. 2017). But modern cells do not promote polymerization using any of these condensing agents, nor through acetylation or phosphorylation of amino groups, as reported for diamidophosphate (Gibard et al. 2017), or acetylation of hydroxides (Bowler et al. 2013); nor do they do so through wet-dry cycles (Rajamani et al. 2008; DeGuzman et al. 2014; Da Silva et al. 2015; Forsythe et al. 2015). Polymerization of cyclic nucleotides in water at temperatures above $75^{\circ} \mathrm{C}$ has been reported (Costanzo et al. 2009, 2012) but these findings have proved 'erratic' to repeat (Morasch et al. 2014; Šponer et al. 2015). Polymerization apparently occurs only in the absence of $\mathrm{Na}^{+}$ions, and ideally in a gradually desiccating environment (Šponer et al. 2015) that has little in common with polymerization in modern cells.

It could be that condensation reactions really did begin through radically different mechanisms, which were later overwritten by enzymatic catalysis. If metabolism were 'invented' in an RNA world that would arguably need to be the case. On the other hand, if intermediary metabolism arose initially from geochemical flux, via conserved intermediates, then it might be that polymerizations in water are genuinely difficult to achieve, and arose later in a world of organic monomer catalysts. If that were the case, the fact that AcP promoted the synthesis of ATP from ADP - as it still does in modern cells (Ferry and House 2006; Schönheit et al. 2016) - might be important, as both amino acid and nucleotide polymerization depends on nucleotide triphosphates today. The concept of a 'monomer world' is not new (Copley et al. 2007), and could be highly structured, as the formation of fatty acids is favoured under a wide range of conditions (Amend et al. 2013), and spontaneously form bilayer vesicles when above a threshold concentration (Morowitz et al. 1988; Segré et al. 2001). The possibility of a 
rudimentary form of heredity, based on several linked positive feedbacks in growing protocells, is consistent with the idea that polymerization to form macromolecules occurred relatively late (West et al. 2017). If so, then AcP could potentially drive prebiotic chemistry towards a form of proto-metabolism that prefigures the metabolic pathways of modern cells, in which relatively unreactive precursors are activated through phosphorylation. AcP therefore begins to bridge the gap between prebiotic chemistry and monomer biochemistry in living cells, but does not directly promote the formation of macromolecules.

The phosphorylation reactions reported here required high concentrations of reagents, and could be criticised for being prebiotically implausible (McCollom 2013). While the concentrations we used are similar to those reported for most other studies (Lohrmann and Orgel 1968; Rabinowitz 1970; Chung et al. 1971; Yamagata et al. 1991; Bujdák and Rode 1996; Liu and Orgel 1997; Huber et al. 2003; Leman et al. 2004; Costanzo et al. 2007; DeGuzman et al. 2014; Morasch et al. 2014; Burcar et al. 2015), three factors make these high concentrations more realistic in alkaline hydrothermal systems. First, deep-sea hydrothermal systems are at high pressure (100300 Bars) which increases the solubility, and so concentration, of gases such as $\mathrm{H}_{2}$. Pressure also increases the likelihood of molecular collisions, which is equivalent to increasing the concentration of reactants or raising the temperature. Continuous hydrothermal flux sustains the critical disequilibria in $\mathrm{H}_{2}, \mathrm{CO}_{2}$ and proton concentrations, and should theoretically drive organic synthesis, including formation of thioacetate and acetyl phosphate, under these conditions (Amend and Shock 1998; Shock and Canovas 2010; Amend et al. 2013; Sojo et al. 2016). Second, thermal gradients and convection currents in alkaline hydrothermal vents can concentrate organics by thermophoresis. Steep heat gradients produced by lasers in closed glass capillaries concentrate nucleotides and small RNAs by $10^{3}-10^{12}$-fold (Braun and Libchaber 2002; Baaske et al. 2007; Mast and Braun 2010; Mast et al. 2013). In simulated hydrothermal systems, we have shown that thermophoresis across an open, inert microporous matrix can concentrate small organics equivalent to nucleotides by at least 5000-fold (Herschy et al. 2014). Third, the charge on phosphorylated biomolecules such as acetyl phosphate makes them more likely to interact with mineral surfaces within hydrothermal vents, promoting their retention in vent pores rather than their discharge from the vent along with uncharged 'waste' molecules such as methane (Westheimer 1987; Pratt 2006; Mellersh and Smith 2010). Similarly, if monomers were formed inside fatty acid vesicles, with 'autotrophic' growth driven by geologically sustained gradients across the membranes (West et al. 2017), molecular crowding and membrane surface associations inside growing protocells would also increase local concentrations. These three factors mean that the concentrations used in this study, while high, are not necessarily unreasonable.

In conclusion, we report that AcP is readily synthesised under ambient and mild hydrothermal conditions, and promotes phosphorylation reactions in water, without catalysts, under a wide range of conditions. Most of the conclusions of this paper apply equally to other prebiotic environments, and do not need to be interpreted in a hydrothermal context. All reactions reported here, including those under ambient conditions, occur over time scales of minutes to hours, giving dynamics that approach those of living cells, rather than geological systems, even in the absence of catalysts. We believe that these findings make AcP a credible primordial energy currency, coupling carbon and energy flux at the origin of life. The fact that AcP promotes phosphorylation but not condensation reactions in water points to a period of monomer biochemistry before the emergence of polymeric enzymes or ribozymes at the origin of life (Copley et al. 2007). This conception is consistent with autotrophic origins and rudimentary heredity in growing protocells before the emergence of RNA, polypeptides, and true genetic heredity (West et al. 2017). The biochemical utility of AcP may be limited by its tendency to acetylate amino groups. But in 
driving the synthesis of ATP from ADP, AcP might have helped bridge the gap between monomer biochemistry and the origin of genetic replicators.

\section{Methods}

\section{Synthesis of Acetyl Phosphate from Thioacetate}

Solutions of inorganic phosphate $\left(\mathrm{Na}_{2} \mathrm{HPO}_{4}, 20 \mathrm{mM}\right)$ in $10 \% \mathrm{D}_{2} \mathrm{O}$ and Milli-Q water $(18 \mathrm{M} \Omega)$ were prepared with different concentrations $(0,2,10,20 \mathrm{mM})$ of either calcium or magnesium ions $\left(\mathrm{MgCl}_{2}, \mathrm{CaCl}_{2}\right)$ or an equimolar mix of both. Thioacetic acid $\left(\mathrm{CH}_{3} \mathrm{COSH}, 40 \mathrm{mM}\right)$ was then added and the $\mathrm{pH}$ adjusted to 6,7 or 8 with aqueous $\mathrm{HCl}$ or $\mathrm{NaOH}(1 \mathrm{M})$. Samples $(600 \mu \mathrm{L})$ were taken at time points $(0,10,20,30,40,50,60,120$ and $180 \mathrm{~min}$ ) and immediately frozen at $-80{ }^{\circ} \mathrm{C}$. Experiments were carried out at $20^{\circ} \mathrm{C}$ and $50{ }^{\circ} \mathrm{C}$. Samples were defrosted and analysed using ${ }^{1} \mathrm{H}-\mathrm{NMR}$ (Bruker Avance $600 \mathrm{MHz} ; 10 \% \mathrm{D}_{2} \mathrm{O}, 16$ scans, water suppression) with potassium hydrogen phthalate (KHP, $1 \mathrm{mM}$ ) as an internal standard. Concentrations were calculated using the integrated ratio of protons in the internal standard compared to AcP. Standards of AcP were measured with ${ }^{1} \mathrm{H}-\mathrm{NMR}$ to confirm the shift of the detected peak within the experiments. KHP was detected between 7.4-7.6 ppm and AcP at 2.1 ppm. All peaks in NMR were identified by analysis of both pure standards and spiking of experimental samples. To every time point 15 min was added to take into account time taken from defrosting to start of analysis.

For the results in the supplementary materials, the same experiments were carried out at pH 11 with calcium and magnesium ions, at $\mathrm{pH} 7$ with $\mathrm{Fe}^{2+}$ ions at differing concentrations $(200,400$ and $1000 \mu \mathrm{M})$ in anaerobic conditions, and at $\mathrm{pH} 7$ in both aerobic and anaerobic conditions.

\section{Phosphorylation of Ribose in Water}

Solutions of D-ribose $(0.3 \mathrm{M})$ and $\mathrm{AcP}(0.3 \mathrm{M})$ were prepared and, when applicable, aqueous solutions containing $\mathrm{MgCl}_{2}, \mathrm{CaCl}_{2}$ or boric acid $\left(\mathrm{H}_{3} \mathrm{BO}_{3}\right)$ were added $(0.15 \mathrm{M})$. Experiments were performed at $\mathrm{pH} 7,9$ and 11 at $20{ }^{\circ} \mathrm{C}$ and $50{ }^{\circ} \mathrm{C}$, and samples taken at 2, 30, 60, 120, $300 \mathrm{~min}$, and 1, 2 and 5 days. Quantification was performed using LC-MS (Finnigan LTQ Thermo Fischer; Accela 600 pump and autosampler; column: Hypersil Gold $(150 \times 2.1 \mathrm{~mm}, 1.9 \mu \mathrm{L})$, in ESI positive mode. Mobile phase solvents were (A) water/0.1\% formic acid (FA) and (B) acetonitrile/ $0.1 \% \mathrm{FA}$, at a flow rate of $200 \mu \mathrm{L} / \mathrm{min}$. The optimal solvent gradient started with $98 \% \mathrm{~A}$, and went gradually down to $5 \% \mathrm{~A}$ at $18 \mathrm{~min}$; after holding 5\% A for $1 \mathrm{~min}$, the gradient went to the initial conditions $(98 \%$ A) for the last $5.5 \mathrm{~min}$. Samples were derivatised using 3-amino-9-ethylcarbazole (Han et al. 2013) and further purified using solid phase extraction (SPE) protocol (HyperSep, C18 $500 \mathrm{mg} / \mathrm{mL}$ ), followed by a $0.22 \mu \mathrm{m}$ microfiltration. Ribose-5-phosphate was identified using retention time, and primary and MSMS fragmentation pattern of standards; quantification was performed using calibration curves for each experimental condition $(\mathrm{pH}$ and ion concentration). Electron ionisation mass spectrometry showed the precursor ion $425.14 \mathrm{~m} / \mathrm{z}$ for the derivatised ribose-5-phosphate; this was used for quantification. Molecular ion $521.13 \mathrm{~m} / \mathrm{z}$ was also monitored, which corresponds to tetraacetylated ribose at $\mathrm{pH} 11$. 


\section{Phosphorylation of Adenosine in Water}

Solutions of adenosine $(2 \mathrm{mM})$ and $\mathrm{AcP}(800 \mathrm{mM})$ were prepared and $\mathrm{pH}$ adjusted to 7, 9 or 11. Samples $(500 \mu \mathrm{L})$ were taken at 1, 5, 24, 48 and $144 \mathrm{~h}$, diluted to $1 \mathrm{~mL}$ with Milli-Q water (18 M $\Omega$ ) and frozen. Samples were analysed on a Dionex HPLC, using a TELOS AT dC18 $(100 \times 4.6 \mathrm{~mm})$ column, with mobile phases; A: $150 \mathrm{mM} \mathrm{KH}_{2} \mathrm{PO}_{4}$ and $150 \mathrm{mM} \mathrm{KCl}, \mathrm{B}: 15 \%$ $v / \mathrm{v}$ acetonitrile in phase A. Peaks were identified using pure standards and spiked samples and quantified using standard calibration curves.

\section{Phosphorylation of ADP in Water}

Equimolar solutions $(0.5 \mathrm{M})$ of $\mathrm{ADP}$ and $\mathrm{AcP}$ were prepared and mixed. The $\mathrm{pH}$ was adjusted to 5.5 with aqueous $\mathrm{HCl}$ or $\mathrm{NaOH}(1 \mathrm{M})$ and samples $(500 \mu \mathrm{L})$ were taken at time-points $(1,2,3,4$ and $5 \mathrm{~h})$ and immediately frozen at $-80{ }^{\circ} \mathrm{C}$. Experiments were carried out at 20 and $50{ }^{\circ} \mathrm{C}$. Samples were thawed and analysed using ${ }^{31} \mathrm{P}-\mathrm{NMR}$ $\left({ }^{1} \mathrm{H}\right.$ decoupling, Bruker Avance $400 \mathrm{MHz}, 152$ scans) and peaks were identified using pure standards. The quantification and statistical analysis were carried out by extrapolating the absolute intensity of the peaks of interest (in the case of ATP, the average absolute intensity of the three peaks formed by the $\beta$-phosphate, $\mathrm{P}_{\beta}$ ) and using standard calibration curves.

For the results in the supplementary materials, the same experiments were carried out with mixed equimolar solutions $(250 \mu \mathrm{M})$ of ADP and AcP at pH 5.5 at $50{ }^{\circ} \mathrm{C}$. Samples $(1 \mathrm{~mL})$ were taken at time-points $(1,2,3,4$ and $5 \mathrm{~h})$ and frozen at $-80{ }^{\circ} \mathrm{C}$. Samples were thawed and analysed on a Dionex HPLC, using an Acclaim $120 \mathrm{C} 182.2 \mu \mathrm{m}$ column $(2.1 \times 250 \mathrm{~mm})$, with mobile phases A: $0.1 \mathrm{M}$ ammonium acetate, B: $100 \%$ acetonitrile. The column flow rate was set at $0.1 \mathrm{~mL} / \mathrm{min}$, and the column temperature was maintained at room temperature. The optimal elution gradient was determined to be: from $100 \%$ to $95 \%$ A during the first 5 min, then up to $75 \%$ A for $6.3 \mathrm{~min}$ and held at $75 \%$ A for $8.7 \mathrm{~min}$. Peaks were identified using pure standards and spiked samples and quantified using standard calibration curves.

\section{Acetylation of Glycine}

Solutions of glycine $(0.5 \mathrm{M})$ were prepared, $\mathrm{pH}$ adjusted to $7,8,9,10,11$ or 12 using $\mathrm{NaOH}$ (1 M), and AcP (0.5 M; prepared as in Crans and Whitesides 1983), or using a commercial preparation) added to each $\mathrm{pH}$ condition. Samples were incubated at $20{ }^{\circ} \mathrm{C}$ for 7 days. Analysis was carried out by ${ }^{1} \mathrm{H}-\mathrm{NMR}$ (Bruker Avance $300 \mathrm{MHz} ; 10 \% \mathrm{D}_{2} \mathrm{O}, 16$ scans, water suppression). All peaks in NMR were identified by analysis of both pure standards and by spiked experimental samples. Percent conversion of glycine to $\mathrm{N}$-acetylglycine was calculated using the integrated ratio of protons by comparable integration of peak areas.

\section{Stacking of Adenosine Monophosphate}

Reactions were carried out in $1.5 \mathrm{~mL}$ Eppendorf tubes with a final volume of $1 \mathrm{~mL}$ containing AMP $(3 \mathrm{mM})$ and AcP $(450 \mathrm{mM})$. No additional ions were added during the initial tests. The tubes were heated when applicable in a block heater to $20{ }^{\circ} \mathrm{C}$, $50{ }^{\circ} \mathrm{C}$ or $75{ }^{\circ} \mathrm{C}$, as it has been claimed some condensation reactions only take place at $75{ }^{\circ} \mathrm{C}$ and above (Šponer et al. 2015). The $\mathrm{pH}$ was adjusted to 5 or 11 using 
solutions of $5 \mathrm{M} \mathrm{HCl}$ and $10 \mathrm{M} \mathrm{NaOH}$. The incubation time for each experiment was of a maximum of $5 \mathrm{~h}$ (as little effect of AcP would be expected any longer, especially at high temperature) although some samples were also taken after 24 and $48 \mathrm{~h}$. Samples were not frozen (in order to store them) as the freeze-thaw process could account for some polymerisation, which would be an artefact in these experiments.

A MALDI matrix consisting of 2,4,6-trihydroxyacetophenone monohydrate (THAP) plus ammonium citrate was used. Two solutions were prepared for the MALDI matrix: $0.0372 \mathrm{~g}$ of THAP were added to $1 \mathrm{~mL}$ of acetonitrile (ACN); $0.045 \mathrm{~g}$ of ammonium citrate dibasic were added to $1 \mathrm{~mL}$ of HPLC water. Each solution was maintained at $4{ }^{\circ} \mathrm{C}$ for a maximum of a week. The required equal volumes of each solution were mixed to obtain the MALDI matrix. A volume of $1 \mu \mathrm{L}$ of freshly prepared matrix solution was mixed with $1 \mu \mathrm{L}$ of sample and deposited onto a clean steel MALDI-TOF plate. The liquid volume was allowed to evaporate for $30 \mathrm{~min}$ before the introduction of the steel plate into the MALDI-TOF instrument. The MALDI-TOF MS analysis was performed using a Waters micro MX mass spectrometer. The analytical conditions were: reflectron and negative ion mode, 280 au of laser power, $2000 \mathrm{~V}$ of pulse, $2500 \mathrm{~V}$ of the detector, $12,000 \mathrm{~V}$ of flight tube, $5200 \mathrm{~V}$ of reflector, $3738 \mathrm{~V}$ of negative anode, and 500 $5000 \mathrm{amu}$ of scan range. The mass spectrometer was routinely calibrated using a lowmolecular-weight oligonucleotide standard (comprising of a DNA 4-mer, 5-mer, 7-mer, 9mer, and 11-mer (Bruker Daltonics)) as external calibrants. Each oligonucleotide standard was initially dissolved in $100 \mu \mathrm{L}$ HPLC water, divided in aliquots and frozen at $-80{ }^{\circ} \mathrm{C}$. A fresh aliquot was used at each analytical calibration.

Acknowledgments We thank Sean Jordan, Finn Werner, John Ward, Julian Evans, Victor Sojo, Frank Harold and Don Braben for discussions and comments on the manuscript. We are grateful to Kersti Karu and Xiaoping Yang for technical assistance with mass spectrometry. AW, BH and NL are grateful to the Leverhulme Trust (RPG-425) and UCL Research Frontiers Origins of Life Programme for funding. NL is grateful to bgc3 for funding. EC is grateful to La Caixa Foundation and UCL for an Impact Fellowship.

Open Access This article is distributed under the terms of the Creative Commons Attribution 4.0 International License (http://creativecommons.org/licenses/by/4.0/), which permits unrestricted use, distribution, and reproduction in any medium, provided you give appropriate credit to the original author(s) and the source, provide a link to the Creative Commons license, and indicate if changes were made.

\section{References}

Amend JP, Shock EL (1998) Energetics of amino acid synthesis in hydrothermal ecosystems. Science 281:16591662

Amend JP, LaRowe DE, McCollom TM, Shock EL (2013) The energetics of organic synthesis inside and outside the cell. Philos Trans R Soc Lond B 368:20120255

Arndt NT, Nisbet EG (2012) Processes on the young earth and the habitats of early life. Annu Rev Earth Planet Sci 40:521-549

Baaske P, Weinert FM, Duhr S et al (2007) Extreme accumulation of nucleotides in simulated hydrothermal pore systems. Proc Natl Acad Sci 104:9346-9351

Baltscheffsy M, Baltscheffsky H (1995) Alternative photophosphorylation, inorganic pyrophosphate synthase and inorganic pyrophosphate. Photosynth Res 46:87-91

Barge LM, Doloboff IJ, Russell MJ et al (2014) Pyrophosphate synthesis in iron mineral films and membranes simulating prebiotic submarine hydrothermal precipitates. Geochim Cosmochim Acta 128:1-12

Barge LM, Branscomb E, Brucato JR et al (2017) Thermodynamics, disequilibrium, evolution: far-from-equilibrium geological and chemical considerations for origin-of-life research. Orig Life Evol Biosph 47:39-56 
Baross JA, Hoffman SE (1985) Submarine hydrothermal vents and associated gradient environments as sites for the origin and evolution of life. Orig Life Evol Biosph 15:327-345

Bowler FR, Chan CKW, Duffy CD et al (2013) Prebiotically plausible oligoribonucleotide ligation facilitated by chemoselective acetylation. Nat Chem 5:383-389

Braakman R, Smith E (2012) The emergence and early evolution of biological carbon-fixation. PLoS Comput Biol 8:e1002455

Branscomb E, Russell MJ (2013) Turnstiles and bifurcators: the disequilibrium converting engines that put metabolism on the road. Biochim Biophys Acta Bioenerg 1827:62-78

Bräsen C, Schmidt M, Grötzinger J, Schönheit P (2008) Reaction mechanism and structural model of ADPforming acetyl-CoA synthetase from the hyperthermophilic archaeon Pyrococcus furiosus: evidence for a second active site histidine residue. J Biol Chem 283:15409-15418

Braun D, Libchaber A (2002) Trapping of DNA by thermophoretic depletion and convection. Phys Rev Lett 89:188103

Buckel W, Thauer RK (2013) Energy conservation via electron bifurcating ferredoxin reduction and proton/ $\mathrm{Na}^{+}$ translocating ferredoxin oxidation. Biochim Biophys Acta Bioenerg 1827:94-113

Bujdák J, Rode BM (1996) The effect of smectite composition on the catalysis of peptide bond formation. J Mol Evol 43:326-333

Burcar BT, Cassidy LM, Moriarty EM et al (2013) Potential pitfalls in MALDI-TOF MS analysis of abiotically synthesized RNA oligonucleotides. Orig Life Evol Biosph 43:247-261

Burcar BT, Barge LM, Trail D et al (2015) RNA oligomerization in laboratory analogues of alkaline hydrothermal vent systems. Astrobiology 15:509-522

Camprubi E, Jordan SF, Vasiliadou R, Lane N (2017) Iron catalysis at the origin of life. IUBMB Life 69:373-381

Chandru K, Gilbert A, Butch C et al (2016) The abiotic chemistry of thiolated acetate derivatives and the origin of life. Sci Rep 6:1-11

Chung NM, Lohrmann R, Orgel LE, Rabinowitz J (1971) The mechanism of the trimetaphosphate-induced peptide synthesis. Tetrahedron 27:1205-1210

Copley SD, Smith E, Morowitz HJ (2007) The origin of the RNA world: co-evolution of genes and metabolism. Bioorg Chem 35:430-443

Costanzo G, Saladino R, Crestini C et al (2007) Nucleoside phosphorylation by phosphate minerals. J Biol Chem 282:16729-16735

Costanzo G, Pino S, Ciciriello F, Di Mauro E (2009) Generation of long RNA chains in water. J Biol Chem 284: 33206-33216

Costanzo G, Saladino R, Botta G et al (2012) Generation of RNA molecules by a base-catalysed click-like reaction. ChemBioChem 13:999-1008

Crans DC, Whitesides GM (1983) A convenient synthesis of disodium acetyl phosphate for use in in situ ATP cofactor regeneration. J Organomet Chem 48:3130-3132

Da Silva L, Maurel MC, Deamer D (2015) Salt-promoted synthesis of RNA-like molecules in simulated hydrothermal conditions. J Mol Evol 80:86-97

de Duve C (1988) Did God make RNA? Nature 336:209-210

de Duve C (1991) Blueprint for a cell: the nature and origin of life. Neil Patterson Publishers, Burlington

de Duve C (1998) Clues from present-day biology: the thioester world. In: Brack A (ed) The molecular origins of life. Cambridge University Press, Cambridge, pp 219-236

de Duve C (2005) Singularities. Cambridge University Press, Cambridge

de Zwart II, Meade SJ, Pratt AJ (2004) Biomimetic phosphoryl transfer catalysed by iron(II)-mineral precipitates. Geochim Cosmochim Acta 68:4093-4098

Decker K, Jungermann K, Thauer RK (1970) Energy production in anaerobic organisms. Angew Chem Int Ed Eng 9:138-158

DeGuzman V, Vercoutere W, Shenasa H, Deamer D (2014) Generation of oligonucleotides under hydrothermal conditions by non-enzymatic polymerization. J Mol Evol 78:251-262

Di Sabato G, Jencks WP (1961a) Mechanism and catalysis of reactions of acyl phosphates. I. Nucleophilic reactions. J Am Chem Soc 83:4393-4400

Di Sabato G, Jencks WP (1961b) Mechanism and catalysis of reactions of acyl phosphates. II. Hydrolysis. J Am Chem Soc 83:4400-4405

Etaix E, Buvet R (1975) Conditions of occurrence for premeval processes of transphosphorylations. Orig Life 6:175-183

Ferry JG, House CH (2006) The stepwise evolution of early life driven by energy conservation. Mol Biol Evol 23:1286-1292

Forsythe JG, Yu SS, Mamajanov I et al (2015) Ester-mediated amide bond formation driven by wet-dry cycles: a possible path to polypeptides on the prebiotic earth. Angew Chem Int Ed 54:9871-9875

Fuchs G (2011) Alternative pathways of carbon dioxide fixation: insights into the early evolution of life? Annu Rev Microbiol 1:631-658 
Gibard C, Bhowmik S, Karki M et al (2017) Phosphorylation, oligomerization and self-assembly in water under potential prebiotic conditions. Nat Chem 10:212-217

Goldford JE, Hartman H, Smith TF, Segrè D (2017) Remnants of an ancient metabolism without phosphate. Cell 168:1126-1134

Griesser H, Bechthold M, Tremmel P et al (2017) Amino acid-specific, ribonucleotide-promoted peptide formation in the absence of enzymes. Angew Chem Int Ed 56:1224-1228

Gull M, Mojica MA, Fernández FM, Gaul DA, Orlando TM, Liotta CL, Pasek MA (2015) Nucleoside phosphorylation by the mineral schreibersite. Sci Rep 5:17198

Han J, Tschernutter V, Yang J, Eckle T, Borchers CH (2013) Analysis of selected sugars and sugar phosphates in mouse heart tissue by reductive amination and liquid chromatography-electrospray ionization mass spectrometry. Anal Chem 85:5965-5973. https://doi.org/10.1021/ac400769g

Harel A, Bromberg Y, Falkowski PG, Bhattacharya D (2014) Evolutionary history of redox metal-binding domains across the tree of life. Proc Natl Acad Sci 111:7042-7047

Hedderich R (2004) Energy-converting [NiFe] hydrogenases from archaea and extremophiles: ancestors of complex I. J Bioenerg Biomembr 36:65-75

Herschy B, Whicher A, Camprubi E et al (2014) An origin-of-life reactor to simulate alkaline hydrothermal vents. J Mol Evol 79:213-227

Holm NG (2012) The significance of Mg in prebiotic geochemistry. Geobiology 10:269-279

Huber C, Wächtershäuser G (1997) Activated acetic acid by carbon fixation on (Fe,Ni)S under primordial conditions. Science 276:245-247

Huber C, Eisenreich W, Hecht S, Wächtershäuser G (2003) A possible primordial peptide cycle. Science 301: 938-940

Jauker M, Griesser H, Richert C (2015) Spontaneous formation of RNA strands, peptidyl RNA, and cofactors. Angew Chem Int Ed 54:14564-14569

Kaster A-K, Moll J, Parey K, Thauer RK (2011) Coupling of ferredoxin and heterodisulfide reduction via electron bifurcation in hydrogenotrophic methanogenic archaea. Proc Natl Acad Sci 108:2981-2986

Keller MA, Turchyn AV, Ralser M (2014) Non-enzymatic glycolysis and pentose phosphate pathway-like reactions in a plausible Archean ocean. Mol Syst Biol 10:1-12

Keller MA, Driscoll PC, Messner C, Ralser M (2017a) Primordial Krebs-cycle-like non-enzymatic reactions detected by mass spectrometry and nuclear magnetic resonance. Wellcome Open Res 2:52

Keller MA, Kampjut D, Harrison SA, Ralser M (2017b) Sulfate radicals enable a non-enzymatic Krebs cycle precursor. Nat Publ Group 1:1-9

Kelley DS, Karson JA, Blackman DK et al (2001) An off-axis hydrothermal vent field near the mid-atlantic ridge at 30 degrees N. Nature 412:145-149

Kelley DS, Karson JA, Fru GL et al (2005) A serpentinite-hosted ecosystem: the Lost City hydrothermal field. Science 307:1428-1434

Kim JD, Senn S, Harel A et al (2013) Discovering the electronic circuit diagram of life: structural relationships among transition metal binding sites in oxidoreductases. Philos Trans R Soc Lond B 368:20120257

Kitani A, Tsunetsugu S, Suzuki A et al (1995) Fe(III)-ion-catalysed non-enzymatic transformation of adenosine diphosphate into adenosine triphosphate part II. Evidence of catalytic nature of Fe ions. Bioelectrochem Bioenerg 36:47-51

Kornberg A, Rao NN, Ault-Riché D (1999) Inorganic polyphosphate: a molecule of many functions. Annu Rev Biochem 68:89-125

Koshland DE (1952) Effect of catalysts on the hydrolysis of acetyl phosphate. Nucleophilic displacement mechanisms in enzymatic reactions. J Am Chem Soc 74:2286-2292

Kreysing M, Keil L, Lanzmich S, Braun D (2015) Heat flux across an open pore enables the continuous replication and selection of oligonucleotides towards increasing length. Nat Chem 7:203-208

Lane N (2014) Bioenergetic constraints on the evolution of complex life. Cold Spring Harb Perspect Biol 6: a015982

Lane N (2015) The vital question: energy, evolution and the origins of complex life. WW Norton, New York

Lane N, Martin WF (2012) The origin of membrane bioenergetics. Cell 151:1406-1416

Lane N, Allen JF, Martin W (2010) How did LUCA make a living? Chemiosmosis in the origin of life. BioEssays 32:271-280

Leman L, Orgel L, Ghadiri MR (2004) Carbonyl sulfide-mediated prebiotic formation of peptides. Science 306:283-286

Liu R, Orgel LE (1997) Oxidative acylation using thioacids. Nature 389:52-54

Lohrmann R, Orgel LE (1968) Prebiotic synthesis: phosphorylation in aqueous solution. Science 161:64-66

Martin W, Russell MJ (2003) On the origins of cells: a hypothesis for the evolutionary transitions from abiotic geochemistry to chemoautotrophic prokaryotes, and from prokaryotes to nucleated cells. Philos Trans R Soc B Biol Sci 358:59-85 
Martin W, Russell MJ (2007) On the origin of biochemistry at an alkaline hydrothermal vent. Philos Trans R Soc Lond B 362:1887-1925

Martin W, Baross J, Kelley D, Russell MJ (2008) Hydrothermal vents and the origin of life. Nat Rev Microbiol 6 : 805-814

Martin WF, Sousa FL, Lane N (2014) Energy at life's origin. Science 344:1092-1093

Mast CB, Braun D (2010) Thermal trap for DNA replication. Phys Rev Lett 104:1-4

Mast CB, Schink S, Gerland U, Braun D (2013) Escalation of polymerization in a thermal gradient. Proc Natl Acad Sci U S A 110:8030-8035

McCollom TM (2013) Miller-Urey and beyond: what have we learned about prebiotic organic synthesis reactions in the past 60 years? Annu Rev Earth Planet Sci 41:207-229

Mellersh A, Smith P (2010) The alkaline world and the origin of life. J Cosmol 10:3230-3242

Messner CB, Driscoll PC, Piedrafita G et al (2017) Nonenzymatic gluconeogenesis-like formation of fructose 1, 6-bisphosphate in ice. Proc Natl Acad Sci 114:7403-7407

Milner-White EJ, Russell MJ (2005) Sites for phosphates and iron-sulfur thiolates in the first membranes: 3 to 6 residue anion-binding motifs (nests). Orig Life Evol Biosph 35:19-27

Milner-White EJ, Russell MJ (2011) Functional capabilities of the earliest peptides and the emergence of life. Genes (Basel) 2:671-688

Morasch M, Mast CB, Langer JK et al (2014) Dry polymerization of 3',5'-cyclic GMP to long strands of RNA. ChemBioChem 15:879-883

Morowitz HJ, Heinz B, Deamer DW (1988) The chemical logic of a minimum protocell. Orig Life Evol Biosph 18:281-287

Morowitz HJ, Kostelnik JD, Yang J, Cody GD (2000) The origin of intermediary metabolism. Proc Natl Acad Sci 97:7704-7708

Muchowska KB, Varma SJ, Chevallot-Beroux E et al (2017) Metals promote sequences of the reverse Krebs cycle. Nat Ecol Evol 1:1716-1721

Nitschke W, Russell MJ (2009) Hydrothermal focusing of chemical and chemiosmotic energy, supported by delivery of catalytic Fe, Ni, Mo/W, Co, S and Se, forced life to emerge. J Mol Evol 69:481-496

Nitschke W, McGlynn SE, Milner-White EJ, Russell MJ (2013) On the antiquity of metalloenzymes and their substrates in bioenergetics. Biochim Biophys Acta Bioenerg 1827:871-881

Patel BH, Percivalle C, Ritson DJ et al (2015) Common origins of RNA, protein and lipid precursors in a cyanosulfidic protometabolism. Nat Chem 7:301-307

Pinti DL (2005) The origin and evolution of the oceans. In: Gargaud M, Barbier B, Martin H, Reisse J (eds) Lectures in astrobiology. Springer, Berlin Heidelberg, 1:83-112

Powner MW, Gerland B, Sutherland JD (2009) Synthesis of activated pyrimidine ribonucleotides in prebiotically plausible conditions. Nature 459:239-242

Pratt AJ (2006) The curious case of phosphate solubility. Chem New Zeal 70:78-80

Rabinowitz J (1970) Peptide and amide bond formation in aqueous solutions of cyclic or linear polyphosphates as a possible prebiotic process. Helv Chim Acta 53:1350-1355

Rajamani S, Vlassov A, Benner S et al (2008) Lipid-assisted synthesis of RNA-like polymers from mononucleotides. Orig Life Evol Biosph 38:57-74

Ricardo A, Carrigan MA, Olcott AN, Benner SA (2004) Borate minerals stabilize ribose. Science 303:196-196

Russell M, Hall A (1997) The emergence of life from iron monosulphide bubbles at a submarine hydrothermal redox and $\mathrm{pH}$ front. J Geol Soc Lond 154:377-402

Russell MJ, Martin W (2004) The rocky roots of the acetyl-CoA pathway. Trends Biochem Sci 29:358-363

Russell MJ, Daniel RM, Hall AJ, Sherringham J (1994) A hydrothermally precipitated catalytic iron sulphide membrane as a first step toward life. J Mol Evol 39:231-243

Russell MJ, Barge LM, Bhartia R et al (2014) The drive to life on wet and icy worlds. Astrobiology 14:308-343

Saladino R, Crestini C, Pino S et al (2012) Formamide and the origin of life. Phys Life Rev 9:84-104

Saladino R, Carota E, Botta G et al (2015) Meteorite-catalyzed syntheses of nucleosides and of other prebiotic compounds from formamide under proton irradiation. Proc Natl Acad Sci 112:E2746-E2755

Schönheit P, Buckel W, Martin WF (2016) On the origin of heterotrophy. Trends Microbiol 24:12-25

Segré D, Ben-Eli D, Deamer DW, Lancet D (2001) The lipid world. Orig Life Evol Biosph 31:119-145

Sen S, Pal U, Maiti NC (2014) PKa determination of d-ribose by Raman spectroscopy. J Phys Chem B 118:909-914

Shock E, Canovas P (2010) The potential for abiotic organic synthesis and biosynthesis at seafloor hydrothermal systems. Geofluids 10:161-192

Smith E, Morowitz HJ (2004) Universality in intermediary metabolism. Proc Natl Acad Sci 101:13168-13173

Smith E, Morowitz HJ (2016) The origin and nature of life on earth. Cambridge University Press, Cambridge

Sojo V, Herschy B, Whicher A et al (2016) The origin of life in alkaline hydrothermal vents. Astrobiology 16:181-197

Sousa FL, Thiergart T, Landan G et al (2013) Early bioenergetic evolution. Philos Trans R Soc Lond B 368: 20130088 
Šponer JE, Šponer J, Giorgi A et al (2015) Untemplated nonenzymatic polymerization of 3',5'cGMP: a plausible route to $3^{\prime}, 5^{\prime}$-linked oligonucleotides in primordia. J Phys Chem B 119:2979-2989

Srinivasan V, Morowitz HJ (2009) Analysis of the intermediary metabolism of a reductive chemoautotroph. Biol Bull 217:222-232

Thauer RK, Jungermann K, Decker K (1977) Energy conservation in chemotrophic anaerobic bacteria. Bacteriol Rev 41:100-180

Thauer RK, Kaster AK, Seedorf H et al (2008) Methanogenic archaea: ecologically relevant differences in energy conservation. Nat Rev Microbiol 6:579-591

Wagner T, Koch J, Ermler U, Shima S (2017) Methanogenic heterodisulfide reductase (HdrABC-MvhAGD) uses two noncubane [4Fe-4S] clusters for reduction. Science 357:699-703

Weiss MC, Sousa FL, Mrnjavac N et al (2016) The physiology and habitat of the last universal common ancestor. Nat Microbiol 1:1-8

West T, Sojo V, Pomiankowski A, Lane N (2017) The origin of heredity in protocells. Philos Trans R Soc B 372: 20160419

Westheimer F (1987) Why nature chose phosphates. Science 235:1173-1178

White LM, Bhartia R, Stucky GD, Kanik I, Russell MJ (2015) Mackinawite and greigite in ancient alkaline hydrothermal chimneys: identifying potential key catalysts for emergent life. Earth Planet Sci Lett 430:105114

Woese CR (1977) A comment on methanogenic bacteria and the primitive ecology. J Mol Evol 9:369-371

Yamagata Y, Watanabe H, Saitoh M, Namba T (1991) Volcanic production of polyphosphates and its relevance to prebiotic evolution. Nature 352:516-519 